\section{Architecture and material properties of diatom shells provide effective mechanical protection}

\section{Christian E. Hamm, Rudolf Merkel $\dagger \neq$, Olaf Springer $\$$, Piotr Jurkojc $₫$, Christian Maier $\dagger$, Kathrin Prechtel $\dagger$ \& Victor Smetacek ${ }^{\star}$}

* Alfred Wegener Institute for Polar and Marine Research, Am Handelshafen 12, 27570 Bremerhaven, Germany

$\dagger$ Technische Universität München, Physics Department (Biophysics Group E22), 85748 Garching, Germany

$\ddagger$ Research Centre Jülich, Institute of Thin Films and Interfaces, 52425 Jülich, Germany

$\$$ Hochschule Bremen - University of Applied Science, Neustadtswall 30, 28199 Bremen, Germany

Diatoms are the major contributors to phytoplankton blooms in lakes and in the sea and hence are central in aquatic ecosystems and the global carbon cycle ${ }^{1}$. All free-living diatoms differ from other phytoplankton groups in having silicified cell walls in the form of two 'shells' (the frustule) of manifold shape and intricate architecture $^{2}$ whose function and role, if any, in contributing to the evolutionary success of diatoms is under debate ${ }^{3-5}$. We explored the defence potential of the frustules as armour against predators by measuring their strength. Real and virtual loading tests (using calibrated glass microneedles and finite element analysis) were performed on centric and pennate diatom cells. Here we show that the frustules are remarkably strong by virtue of their architecture and the material properties of the diatom silica. We conclude that diatom frustules have evolved as mechanical protection for the cells because exceptional force is required to break them. The evolutionary arms race between diatoms and their specialized predators will have had considerable influence in structuring pelagic food webs and biogeochemical cycles.

The striking shapes and complex patterns of the silica shells of recent and fossil diatoms ${ }^{2,6}$ bear resemblance to statically sophisticated (that is, stable and lightweight) man-made constructions ${ }^{7}$, suggesting that the frustules physically protect the cells against mechanical challenges. Because a large variety of organisms, ranging from parasitoid and ingesting protists to crustacean zooplankton, successfully feed on diatoms, the original inferred defensive function of the frustules ${ }^{8}$ faded into the background of diatom research. However, in an environment subject to heavy grazing pressure, any mechanism that reduces population mortality qualifies as an effective defence or deterrent. Thus, the course of phytoplankton evolution must be significantly shaped by the 'arms race', and external mechanical protection would be an effective first line of defence'.

To test this hypothesis we measured the forces necessary to break single, living cells of three representative, bloom-forming diatom species-the centric species Thalassiosira punctigera, the much larger Coscinodiscus granii and the pennate species Fragilariopsis kerguelensis. The centric genera are ubiquitous components of diatom blooms and their pillbox shape is widely represented. Owing to the peculiar mode of diatom cell division, the average size of a growing population successively decreases in diameter ${ }^{10}$, so we compared the strengths of large and small cells of T. punctigera as well. We chose F. kerguelensis because it is a prominent species in the Southern Ocean and the dominant component of the diatom ooze accumulating under the Antarctic Circumpolar Current (ACC), which has been attributed to the exceptionally robust nature of its frustules ${ }^{11}$.

We used calibrated glass microneedles to load and break the frustules with defined forces (Fig. 1a-f). T. punctigera cells resisted forces of up to $260 \mu \mathrm{N}$ and $180 \mu \mathrm{N}$ for cells of $50 \mu \mathrm{m}$ and $100 \mu \mathrm{m}$ diameter, respectively (Fig. 1g). Mechanical strength and size were not only inversely related within a single species but also between different species: $C$. granii cells $(130 \mu \mathrm{m}$ diameter) were crushed at lower forces (up to $90 \mu \mathrm{N}$ ) than T. punctigera. F. kerguelensis frustules (longest axis $30 \mu \mathrm{m}$, Fig. 1d, f) broke at $730 \mu \mathrm{N}$ (Fig. 1g). Assuming that the glass needle pressed on an area of $100 \mu \mathrm{m}^{2}$, the pressures resisted ranged between about 1 and $7 \mathrm{~N} \mathrm{~mm}^{-2}$ (equivalent to 100-700 tonnes $\mathrm{m}^{-2}$ ). Much the same forces were required to break frustules of individual cells of the same species or size group tested, regardless of where they were applied.

A three-dimensional finite element model (FEM) of the $F$. kerguelensis frustule (Fig. 2a) was constructed to simulate the glass needle crush tests and to examine the values and distributions of stress within the frustule. Loading the FEM of diatom frustules of F. kerguelensis with external pressures along the girdle region (side), the valve (top and bottom) or across the girdle region created homogeneous, and thus statically favourable, stress distributions within the frustule (Fig. 2b). External pressures on several small patches, simulating a mandible bite, were also well absorbed (Fig. 2c, d): stress concentration was deflected by the transversal ribs (costae), which smoothly absorbed the stress from the fragile areas in between, in which most of the areolae (pores) are located. Removing the ribs and distributing a corresponding amount of material evenly throughout the whole structure increased stress and deformation values in any of the load cases by more than $70 \%$. Thus less than $60 \%$ of the force required to break the frustules of $F$. kerguelensis would be necessary to destroy such a ribless frustule.

The highest stress values within the frustule before failure, calculated with the FEM of F. kerguelensis, and using the load cases described above (a force of $750 \mu \mathrm{N}$ on the valve and on the girdle bands), were remarkably high: more than $540 \mathrm{~N} \mathrm{~mm}^{-2}$ were
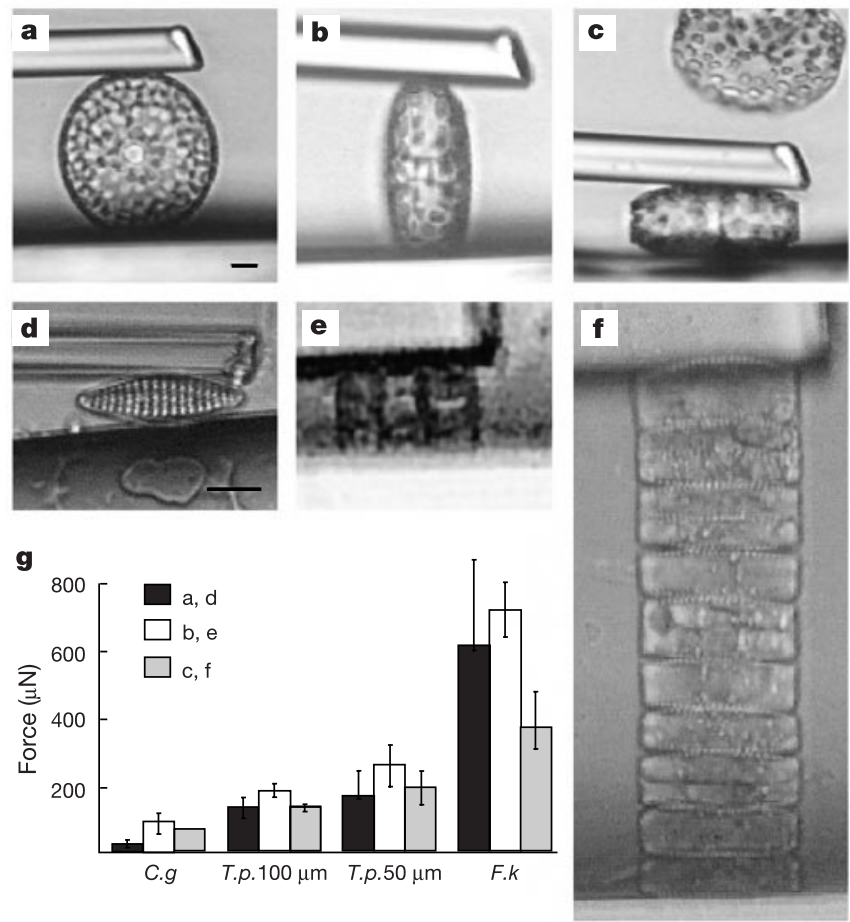

Figure 1 Glass needle tests: Live single cells of $T$. punctigera $(\mathbf{a}-\mathbf{c})$ and $F$. kerguelensis $(\mathbf{d}-\mathbf{f})$, in chains $(\mathbf{e}, \mathbf{f})$. Pressures applied along the girdle bands, $(\mathbf{a}, \mathbf{d})$, across the girdle bands $(\mathbf{b}, \mathbf{e})$, and across the centre of the valves $(\mathbf{c}, \mathbf{f})$. g. Forces necessary to break Coscinodiscus granii (C.g.), Thalassiosira punctigera (T.p.) with diameters of 100 and $50 \mu \mathrm{m}$, and Fragilariopsis kerguelensis (F.k.). C. granii has a geometry similar to that of T. punctigera. Scale bars, $10 \mu \mathrm{m}$. 


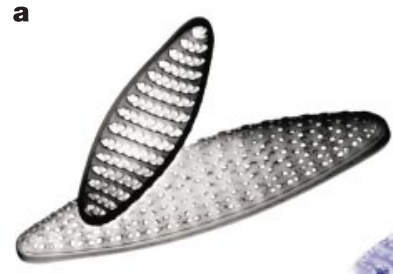

$10 \mu \mathrm{m}$

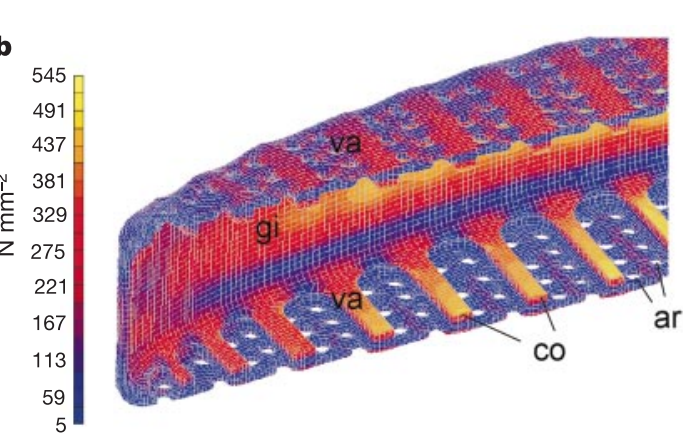

Equivalent von Mises stress

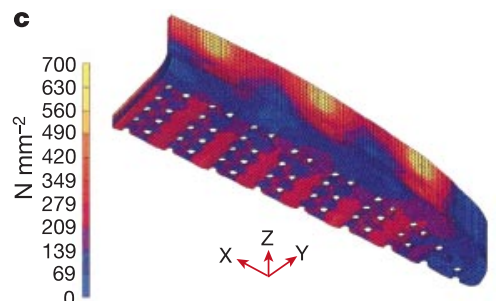

Equivalent von Mises stress

d

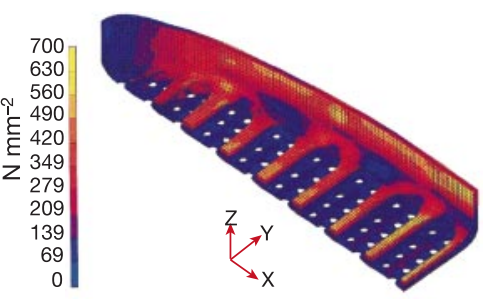

Equivalent von Mises stress
Figure 2 Finite element calculations of $F$. kerguelensis frustules. a, SEM of two valves (left) and rendered FEM of a complete frustule (right). b. Equivalent von Mises stress within the frustule as a function of pressure (total force, $750 \mu \mathrm{N}$ ) on the girdle region. gi, girdle region; va, valve; co, costae; ar, areolae. c, d, One-eighth sections, external (c) and internal (d) views. Equivalent von Mises stress caused by pressure applied on several spots (area of each spot, $1 \mu \mathrm{m}^{2}$; total force, $750 \mu \mathrm{N}$ ), simulating a mandible bite; stress is absorbed by the costae. reached before breakage (Fig. 2b). The values for tensile and compressive stress, depending on whether pressure was applied on the valve face or at the girdle region, were high within the girdle bands (155 and $330 \mathrm{~N} \mathrm{~mm}^{-2}$ ) and in the costae $(560$ and $680 \mathrm{~N} \mathrm{~mm}^{-2}$ ), suggesting that the silica forming the cell wall in this alga should have both high ultimate tensile and high ultimate compressive strengths.

Material properties of diatom silica were evaluated as a function of force by finite element simulation of the real deformation of an isolated pleura (a smooth, open, hoop-shaped segment of the girdle) of $T$. punctigera with a calibrated glass microneedle. The Young's modulus $E$ of the diatom silica of a pleura was $22.4 \mathrm{GPa}$, which is comparable to cortical bone $(20 \mathrm{GPa})^{12}$ or medical dental composites (about 6-25 GPa) ${ }^{13}$. These consist, like diatom silica, of inorganic particles associated with an organic matrix ${ }^{14,15}$. In contrast, glass is much stiffer (about $70 \mathrm{GPa}$ ). Even very strong deformations of the pleura $(2.5 \%$ strain, which causes, at $E=22.4 \mathrm{GPa}$, a stress of about $560 \mathrm{~N} \mathrm{~mm}^{-2}$ ) elicited a completely elastic response. The original shape was regained when the pressure was removed. We were unable to break the pleurae with this method (Fig. 3).

The apparent absence of plastic deformation, which would indicate brittle failure, is consistent with the sharp-edged and smooth fracture sites that appear in broken frustules. However, a recent examination of a fracture in a pennate diatom has shown that the crack leading to fracture did not travel through, but around the minute (about $40 \mathrm{~nm}$ across) silica spheres forming the frustule ${ }^{16}$. This almost doubles the area of the fracture, thereby increasing the amount of energy necessary to break the frustule. In addition, several seconds elapsed before the frustules broke at a certain force,

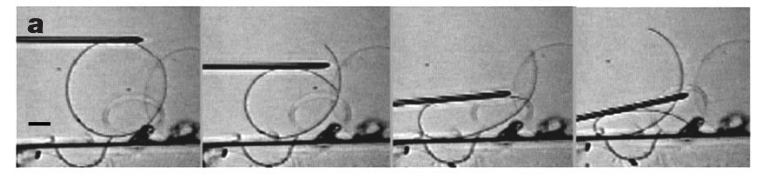

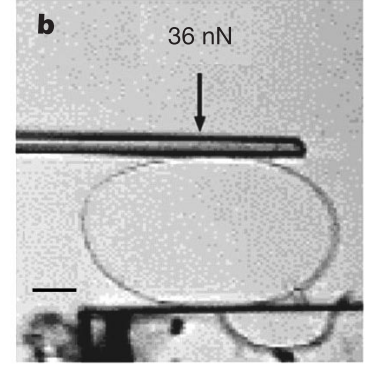

Figure 3 Properties of an isolated girdle band. a, Sequence showing strong elastic deformation of a girdle band as a function of increasing force. $\mathbf{b}$, girdle band (pleura) deformed by a calibrated glass needle. c, FEM of the pleura, showing identical deflections

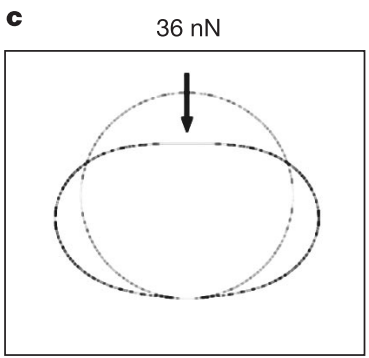

as functions of the same force $(36 \mathrm{nN})$. The Young's modulus $E$ of the silica in the FEM is 22.4 GPa. Scale bars, $10 \mu \mathrm{m}$. 
indicating that creep occurred within the diatom silica, during which energy may have been dissipated by organic material within the composite, in analogy to a recently described process in bone ${ }^{17}$.

Clearly the frustules have evolved to withstand external pressure, and considerable energy and specialized tools are required to break them. Two major zooplankton groups in the ocean-copepods and euphausiids-have silica-edged mandibles and gizzards lined with formidable arrays of sharp 'teeth', respectively ${ }^{18,19}$. These tools are likely to have co-evolved with their diatom prey. Indeed, diatom cells can survive gut passage if they escape being crushed $^{20}$. To generate the approximately $750 \mu \mathrm{N}$ necessary to break F. kerguelensis frustules, the muscle strands operating crushing tools would have to have a diameter of more than $50 \mu \mathrm{m}$ (based on a value of the strongest insect and vertebrate muscles ${ }^{21}$ ). Obviously, only large copepods and euphausiids can break such frustules. Small copepods have been shown to select other prey items ${ }^{22}$.

Although we tested only three species for strength, one for statics and two for material properties, we expect that a combination of balanced statics (lightweight architecture) and toughness of the material is generally present in diatom frustules. In the evolutionary arms race, reducing the numbers of potential predators will bring obvious advantages. It is now widely accepted that diatoms dominate phytoplankton blooms because their mortality rates are lower than those of other, smaller algae with similar growth rates ${ }^{1}$. Our results suggest that the silica frustule is indeed an effective armour against many potential predators, although other specialized predators such as some ciliates ${ }^{23}$ and dinoflagellates ${ }^{24}$ have evolved mechanisms to digest diatom cell contents without breaking or opening the frustules.

Because diatoms play a major role in the ocean's biological carbon pump and in food chains leading to fish, a better understanding of the ecological factors selecting for the species composition of their blooms is called for. We hypothesize that the perplexing variety in shapes and protuberances present in pelagic diatoms have largely evolved as responses to specific predator types ranging from puncturing and ingesting protists to various types of metazooplankton. Diatom frustules fascinate the human eye because of their arresting symmetry, but also because they duplicate, at minute scales, structures and patterns familiar to everyday experience. It seems that these microstructures are not merely 'art forms of nature ${ }^{25}$, but have evolved under selection principles similar to those prevailing in the macroscopic world.

\section{Methods}

\section{Glass needle tests}

Diatoms were cultured at $0{ }^{\circ} \mathrm{C}($ F. kerguelensis $)$ and $15^{\circ} \mathrm{C}$ (T. punctigera, C. granii) under moderate light intensities. Microneedles were drawn from borosilicate glass with a micropipette puller. Microneedles were of cylindrical shape and showed no visual irregularities. These microtools were mounted in a micromanipulator. Experiments were performed in a measurement chamber filled with sea water on the stage of an inverted light microscope equipped with long-distance lenses and differential interference contrast optics. Micrographs were recorded with a charge-coupled device (CCD) camera, stored on videotape, and analysed using the image processing software NIH-Image. Glass needles were calibrated with atomic force microscope (AFM) cantilevers of known spring constants, which resulted in needle deflection as linear functions of applied forces. The pressure on the diatoms was gradually increased until the cells broke. Thus, by measuring the deflection of the needle in the relaxed state and directly before the cells broke, we could determine the maximal forces the cells were able to resist. Thicker and stiffer needles, which exceeded the range where the procedure described above was practicable, were calibrated by directly relating their deflections to forces that were measured on a microbalance. On the basis of the symmetries of the diatoms, we applied pressure with a glass microneedle from three different positions: (1) along the girdle bands, (2) across the girdle bands, and (3) across the centre of the valves.

\section{Finite element modelling and calculations}

An all-hexahedral finite element mesh of $F$. kerguelensis was generated with the finite element program 'MSC Marc Mentat' on the basis of micrographs (scanning electron and light microscopy, SEM and LM), and volume elements (hex 8) were used to construct the geometry. Hexahedral elements are generally preferred over tetrahedra in engineering ${ }^{26}$. Resolution was around 350 elements $\mu \mathrm{m}^{-3}$. We assumed symmetry in three planes. The load cases applied in the crash tests were simulated applying face pressure on the areas where the glass needle was in contact with the diatom frustule. The complexity of diatom architecture and limitations in computing power forced us to simplify some parts of the structures (for example, in the girdle band region). The latter problem became less severe since the first finite element calculations on diatom frustules ${ }^{27}$, but is not solved yet. For the same reasons, the raphe of F. kerguelensis, a slit extending over one edge of the valve, was not included in the model. We assumed statical symmetry of the valve, as the statical disturbance of the raphe is typically compensated for by structural reinforcements. Thus, our conclusions regarding the functional principles of the structure and the material properties should hardly be influenced by these reductions to the essential components.

\section{Young's modulus}

Organic matter was removed from diatoms in a monospecific culture of T. punctigera. Purified siliceous components of the frustules consisted of the valves, the valvocopulae, the copulae and the pleurae; the geometrically simple pleurae were chosen to perform load tests with glass microneedles. The geometry of the pleura was investigated using SEM images of the cross-section of a broken pleura. Deformation as a function of applied force was calculated using glass needle tests (as above). The pleura was subsequently modelled using plate elements with a thickness of 140 and $70 \mathrm{~nm}$. In accordance with the real load tests, the model was loaded with $10-40 \mathrm{nN}$ within the finite element program under an assumed $E$-modulus. Deformation as a function of force was calculated and the $E$-modulus modified until real and virtual tests yielded identical results.

Received 29 August; accepted 24 December 2002; doi:10.1038/nature01416.

1. Smetacek, V. Diatoms and the ocean carbon cycle. Protist 150, 25-32 (1999).

2. Round, F. E., Crawford, R. M. \& Mann, D. G. The Diatoms: Biology and Morphology of the Genera (Cambridge Univ. Press, Cambridge, UK, 1990).

3. Tilman, D. \& Kilham, P.. Sinking in freshwater phytoplankton: Some ecological implications of cell nutrient status and physical mixing processes. Limnol. Oceanogr. 21, 409-417 (1976).

4. Hale, M. S. \& Mitchell, J. G. Functional morphology of diatom frustule microstructures: hydrodynamic control of Brownian particle diffusion and advection. Aquat. Microb. Ecol. 24, 287-295 (2001)

5. Milligan, A. J. \& Morel, F. M. M. A proton buffering role for silica in diatoms. Science 297, 1848-1850 (2002).

6. Gersonde, R. \& Harwood, D. M. Lower Cretaceous diatoms from ODP Leg 113 site 693 (Weddell Sea). Part 1: vegetative cells. Proc. ODP Sci. Res. 113, 365-402 (1990).

7. Burkhardt, B. \& Bach, K. Diatoms 1-Shells in Nature and Technics (Cramer, Braunschweig, 1984).

8. Ehrenberg, C. G. Die Infusionsthierchen als vollkommene Organismen. Ein Blick in das tiefere organische Leben der Natur (Leopold Voss, Leipzig, 1838).

9. Smetacek, V. A watery arms race. Nature 411, 745 (2001).

10. Round, F. E. The problem of reduction of cell size during diatom cell division. Nova Hedwigia 23, 291-303 (1972).

11. Verity, P. G. \& Smetacek, V. Organism life cycles, predation, and the structure of marine pelagic ecosystems. Mar. Ecol. Prog. Ser. 130, 277-293 (1996).

12. Ashman, R. B., Cowin, S. C., Van Buskirk, W. C. \& Rice, J. C. A continuous wave technique for the measurement of the elastic properties of cortical bone. J. Biomech. 17, 349-361 (1984).

13. Willems, G., Lambrechts, P., Braem, M., Celis, J. P. \& Vanherle, G. A classification of dental composites according to their morphological and mechanical characteristics. Dent. Mater. 8, 310-319 (1992).

14. Kröger, N., Deutzmann, R. \& Sumper, M. Polycationic peptides from diatom biosilica that direct silica nanosphere formation. Science 286, 1129-1132 (1999).

15. Fortin, D. \& Vargas, M. A. The spectrum of composites: new techniques and materials. J. Am. Dental Assoc. 131, 26-30 (2000)

16. Crawford, S. A., Higgins, M. J., Mulvaney, P. \& Wetherbee, R. Nanostructure of the diatom frustule as revealed by atomic force and scanning electron microscopy. J. Phycol. 37, 543-554 (2001).

17. Thompson, J. B. et al. Bone indentation recovery time correlates with bond reforming time. Nature 414, 773-776 (2001).

18. Sullivan, B. K., Miller, C. B., Peterson, W. T. \& Soeldner, A. H. A scanning electron microscopy study of the mandibular morphology of boreal copepods. Mar. Biol. 30, 175-182 (1975).

19. Suh, H. L. The gastric mill of euphausiid crustaceans: a comparison of eleven species. Hydrobiologia 321, 235-244 (1996).

20. Fowler, S. W. \& Fisher, N. S. Viability of marine phytoplankton in zooplankton fecal pellets. Deep-Sea Res. 30, 963-969 (1983).

21. Weis-Fogh, T. \& Alexander, R. M. in Scale Effects in Animal Locomotion (ed. Pedley, T. J.) 511-525 (Academic, London, 1977).

22. Atkinson, A. Omnivory and feeding selectivity in five copepod species during spring in the Bellingshausen Sea, Antarctica. ICES J. Mar. Sci. 52, 385-396 (1995).

23. Smetacek, V. The annual cycle of protozooplankton in the Kiel Bight. Mar. Biol. 63, 1-11 (1981).

24. Jacobson, D. M. A brief history of dinoflagellate feeding research. J. Eukaryot. Microbiol. 46, 376-381 (1999).

25. Haeckel, E. Kunstformen der Natur (Bibliographisches Institut, Leipzig/Vienna, 1904).

26. Cifuentes, A. O. \& Kalbag, A. A performance study of tetrahedral and hexahedral elements in 3-D finite element structural analysis. Finite Elements Anal. Des. 12, 313-318 (1992).

27. Steucek, G. \& Schmid, A.-M. M. in Beiträge zum 1. internationalen Symposion des Sonderforschungsbereiches 230 Natürliche Konstruktionen, Leichtbau in Architektur und Natur Teil 2 194-203 (Sprint-Druck GmbH, Stuttgart, 1989).

Acknowledgements We thank F. Hinz and R. Crawford for the SEM image of F. kerguelensis. U. Riebesell, D. Wolf-Gladrow, U. Bathmann and R. Crawford provided comments.

Competing interests statement The authors declare that they have no competing financial interests.

Correspondence and requests for materials should be addressed to C.E.H.

(e-mail: chamm@awi-bremerhaven.de). 